\title{
Editorial
}

\section{Welcome to Seminars in Thrombosis \& Hemostasis 2018. New (2016) Impact Factor and Most Highly Cited Papers}

\author{
Emmanuel J. Favaloro, PhD, FFSc (RCPA) ${ }^{1}$ \\ 1 Department of Haematology, Centres for Thrombosis and \\ Haemostasis, Institute of Clinical Pathology and Medical Research, \\ Westmead Hospital, Westmead, New South Wales, Australia
}

Semin Thromb Hemost 2018;44:1-4.

Welcome to the start of another year with Seminars in Thrombosis \& Hemostasis (STH), this being my 10th year anniversary as the editor in chief. As always, I wish to again sincerely thank all contributors to STH over the years, as well as guest editors for past issues and of course the current and past editorial team. There has been no major overhaul of the editorial team, although some adjustments have occurred and will continue to occur over the next year.

I will also take this opportunity to thank the journal production team at Thieme Medical Publishers for their high production standards and for facilitating both the print and online issues of the journal. In particular, I would like to thank Subhankar De, the production editor for STH, and his production team, as well as Wakiko Ishii, an assistant acquisitions editor, for ongoing support. Subhankar De decided to move from his position in mid-2017 and has been ably replaced by Ananya Das. We wish Subhankar the best of fortune for his future career and warmly welcome Ananya to the team.

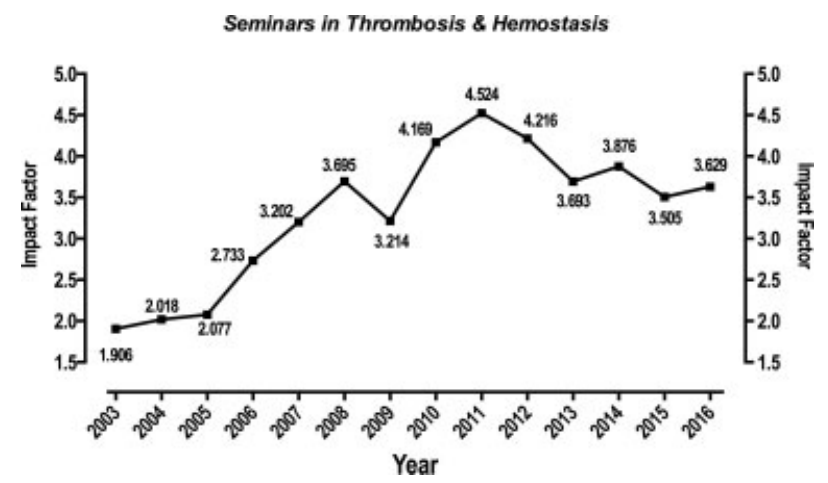

Fig. 1 The Impact Factor for Seminars in Thrombosis \& Hemostasis from 2003 to 2016.

Address for correspondence Emmanuel J. Favaloro, PhD, FFSc (RCPA), Department of Haematology, Centres for Thrombosis and Haemostasis, Institute of Clinical Pathology and Medical Research, Westmead Hospital, Westmead, New South Wales, 2145, Australia (e-mail: emmanuel. favaloro@health.nsw.gov.au).

This is also the time that we reflect on our journal's Impact Factor, which for 2016 was 3.629, which represents a small increase from our 2015 Impact Factor of 3.505 (-Fig. 1). As previously expressed, I am hopeful that this reflects some stabilization of the STH Impact Factor. I also assessed the trends for Impact Factor changes excluding self-citations, and this also reflects positively for recent data (-Fig. 2). Nevertheless, the Impact Factor is only one of several markers of journal "quality" that we should consider, and the limitations of any individual marker (including the Impact Factor) as a "quality" indicator. ${ }^{1,2}$

As I also do annually now, the highest cited (2014/2015 published) contributions ${ }^{3-29}$ from this journal are listed in -Table 1 for the potential interest of the readership and contributing authors. These contributions identify those publications contributing most to the 2016 Impact Factor, and each

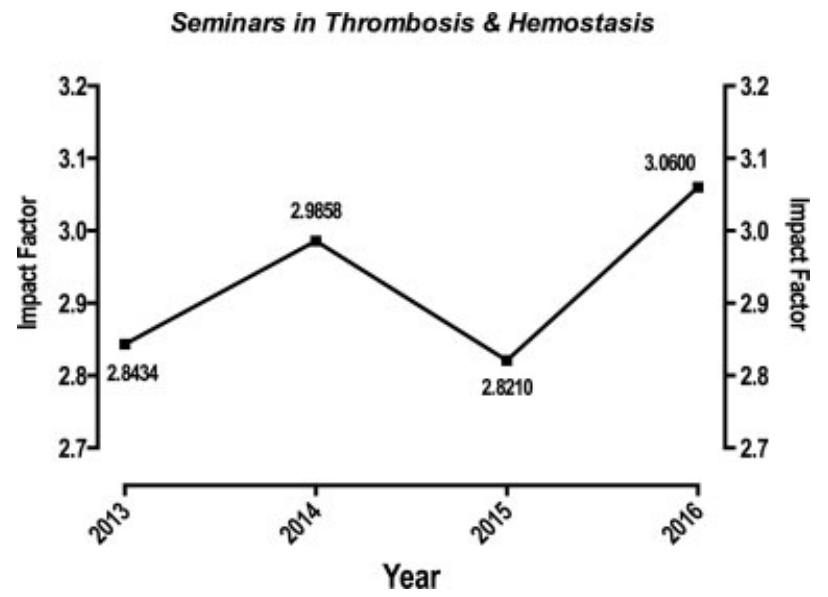

Fig. 2 Most recent changes in the Impact Factor for Seminars in Thrombosis \& Hemostasis excluding self-citations.

Copyright $\odot 2018$ by Thieme Medical Publishers, Inc., 333 Seventh Avenue, New York, NY 10001, USA.

Tel: +1(212) 584-4662.
DOI https://doi.org/ 10.1055/s-0037-1613695. ISSN 0094-6176. Nonbiologic Surfaces; Guest Editors: Hau C. Kwaan, MD, FRCP, and Jun Teruya, MD, DSc, FCAP. 
Table 1 Top-cited papers in 2016, as published in 2014/2015

1. Favaloro EJ, Lippi G. Laboratory testing in the era of direct or non-vitamin K antagonist oral anticoagulants: a practical guide to measuring their activity and avoiding diagnostic errors. Semin Thromb Hemost 2015;41(2):208-227

2. Dorgalaleh A, Naderi M, Hosseini MS, et al. Factor XIII deficiency in Iran: a comprehensive review of the literature. Semin Thromb Hemost 2015;41(3):323-329

3. Rodríguez de Córdoba S, Hidalgo MS, Pinto S, Tortajada A. Genetics of atypical hemolytic uremic syndrome (aHUS). Semin Thromb Hemost 2014;40(4):422-430

4. Warkentin TE. Heparin-induced thrombocytopenia in critically ill patients. Semin Thromb Hemost 2015;41(1):49-60

5. Cuker A. Clinical and laboratory diagnosis of heparin-induced thrombocytopenia: an integrated approach. Semin Thromb Hemost 2014;40(1):106-114

6. Demers M, Wagner DD. NETosis: a new factor in tumor progression and cancer-associated thrombosis. Semin Thromb Hemost 2014;40(3):277-283

7. Riedl M, Fakhouri F, Le Quintrec M, et al. Spectrum of complement-mediated thrombotic microangiopathies: pathogenetic insights identifying novel treatment approaches. Semin Thromb Hemost 2014;40(4):444-464

8. Cervellin G, Lippi G. Of Mls and men-a historical perspective on the diagnostics of acute myocardial infarction. Semin Thromb Hemost 2014;40(5):535-543

9. Dentali F, Sironi AP, Ageno W, Crestani S, Franchini M. ABO blood group and vascular disease: an update. Semin Thromb Hemost 2014;40(1):49-59

10. Yee A, Kretz CA. Von Willebrand factor: form for function. Semin Thromb Hemost 2014;40(1):17-27

11. Levi M, Poll TV. Coagulation in patients with severe sepsis. Semin Thromb Hemost 2015;41(1):9-15

12. Flood VH. Perils, problems, and progress in laboratory diagnosis of von Willebrand disease. Semin Thromb Hemost 2014;40(1):41-48

13. Ranucci M. Hemostatic and thrombotic issues in cardiac surgery. Semin Thromb Hemost 2015;41(1):84-90

14. McEwen BJ. The influence of diet and nutrients on platelet function. Semin Thromb Hemost 2014;40(2):214-226

15. Goubran HA, Stakiw J, Radosevic M, Burnouf T. Platelet-cancer interactions. Semin Thromb Hemost 2014;40(3):296-305

16. Johansen ME, Johansson PI, Ostrowski SR, et al. Profound endothelial damage predicts impending organ failure and death in sepsis. Semin Thromb Hemost 2015;41(1):16-25

17. Moore GW. Recent guidelines and recommendations for laboratory detection of lupus anticoagulants. Semin Thromb Hemost 2014;40(2):163-171

18. Yamamoto K, Takeshita K, Saito H. Plasminogen activator inhibitor-1 in aging. Semin Thromb Hemost 2014;40(6):652-659

19. Franchini M, Favaloro EJ, Lippi G. Newer hemostatic agents. Semin Thromb Hemost 2015;41(7):802-808

20. Levi M, van der Poll T. A short contemporary history of disseminated intravascular coagulation. Semin Thromb Hemost 2014;40(8):874-880

21. Falanga A, Marchetti M. Thrombosis in myeloproliferative neoplasms. Semin Thromb Hemost 2014;40(3):348-358

22. De Stefano V, Za T, Rossi E. Venous thromboembolism in multiple myeloma. Semin Thromb Hemost 2014;40(3):338-347

23. Mallett SV. Clinical utility of viscoelastic tests of coagulation (TEG/ROTEM) in patients with liver disease and during liver transplantation. Semin Thromb Hemost 2015;41(5):527-537

24. Semeraro N, Ammollo CT, Semeraro F, Colucci M. Coagulopathy of acute sepsis. Semin Thromb Hemost 2015;41(6):650-658

25. Suades R, Padró T, Badimon L. The role of blood-borne microparticles in inflammation and hemostasis. Semin Thromb Hemost 2015;41(6):590-606

26. Turner N, Nolasco L, Nolasco J, Sartain S, Moake J. Thrombotic microangiopathies and the linkage between von Willebrand factor and the alternative complement pathway. Semin Thromb Hemost 2014;40(5):544-550

27. Xiao X, Pickering MC, Smith RJ. C3 glomerulopathy: the genetic and clinical findings in dense deposit disease and c3 glomerulonephritis. Semin Thromb Hemost 2014;40(4):465-471

${ }^{\mathrm{a}}$ Thus, contributing most to the 2016 Impact Factor.

have now been cited eight or more times in literature. For those interested, the current listing can be compared with those of the most recently published top downloaded article listings from STH, the basis of the Eberhard F. Mammen "Most Popular" awards, ${ }^{29,30}$ as well as the most recent announcement for the "Young Investigator awards". ${ }^{1}$ Accordingly, I would like to thank all the contributors, guest editors, and the editorial team for bringing us the content that makes STH. 
Table 2 Current planned topics for future issues of Seminars in Thrombosis \& Hemostasis

\begin{tabular}{|l}
\hline Editorial compilations (continuing series) \\
\hline $\begin{array}{l}\text { Recent advances in thrombosis and hemostasis } \\
\text { (continuing series) }\end{array}$
\end{tabular}

Recent developments in antiphospholipid antibodies and the antiphospholipid syndrome

Extrahemostatic functions of platelets and coagulation factors

Alloantibodies and congenital bleeding disorders: new insights into pathogenesis and management

Hemostasis and thrombosis in extreme physiological and pathological conditions

Nanotechnology in thrombosis and hemostasis

Finally, a short note to confirm that, as always, we will continue to develop plans for the future content of this journal, and we are confident that we will be able to continue to bring its readers the high-quality journal that is expected of us. Currently confirmed topics for issues that we plan to publish over the next 12 or so months are listed in - Table 2 . At the same time, we recognize the need to retain some flexibility in our plans and to potentially add additional material of current interest and controversy as the need arises. We look forward to another interesting year of reading in 2018.

\section{References}

1 Favaloro EJ. The Journal Impact Factor: don't expect its demise any time soon. Clin Chem Lab Med 2009;47(11):1319-1324

2 Favaloro EJ. Measuring the quality of journals and journal articles: the impact factor tells but a portion of the story. Semin Thromb Hemost 2008;34(01):7-25

3 Favaloro EJ, Lippi G. Laboratory testing in the era of direct or nonvitamin $\mathrm{K}$ antagonist oral anticoagulants: a practical guide to measuring their activity and avoiding diagnostic errors. Semin Thromb Hemost 2015;41(02):208-227

4 Dorgalaleh A, Naderi M, Hosseini MS, et al. Factor XIII deficiency in Iran: a comprehensive review of the literature. Semin Thromb Hemost 2015;41(03):323-329

5 Rodríguez de Córdoba S, Hidalgo MS, Pinto S, Tortajada A. Genetics of atypical hemolytic uremic syndrome (aHUS). Semin Thromb Hemost 2014;40(04):422-430

6 Warkentin TE. Heparin-induced thrombocytopenia in critically ill patients. Semin Thromb Hemost 2015;41(01):49-60

7 Cuker A. Clinical and laboratory diagnosis of heparin-induced thrombocytopenia: an integrated approach. Semin Thromb Hemost 2014;40(01):106-114

8 Demers M, Wagner DD. NETosis: a new factor in tumor progression and cancer-associated thrombosis. Semin Thromb Hemost 2014;40(03):277-283
9 Riedl M, Fakhouri F, Le Quintrec M, et al. Spectrum of complement-mediated thrombotic microangiopathies: pathogenetic insights identifying novel treatment approaches. Semin Thromb Hemost 2014;40(04):444-464

10 Cervellin G, Lippi G. Of MIs and men-a historical perspective on the diagnostics of acute myocardial infarction. Semin Thromb Hemost 2014;40(05):535-543

11 Dentali F, Sironi AP, Ageno W, Crestani S, Franchini M. ABO blood group and vascular disease: an update. Semin Thromb Hemost 2014;40(01):49-59

12 Yee A, Kretz CA. Von Willebrand factor: form for function. Semin Thromb Hemost 2014;40(01):17-27

13 Levi M, Poll Tv. Coagulation in patients with severe sepsis. Semin Thromb Hemost 2015;41(01):9-15

14 Flood VH. Perils, problems, and progress in laboratory diagnosis of von Willebrand disease. Semin Thromb Hemost 2014;40(01):41-48

15 Ranucci M. Hemostatic and thrombotic issues in cardiac surgery. Semin Thromb Hemost 2015;41(01):84-90

16 McEwen BJ. The influence of diet and nutrients on platelet function. Semin Thromb Hemost 2014;40(02):214-226

17 Goubran HA, Stakiw J, Radosevic M, Burnouf T. Platelet-cancer interactions. Semin Thromb Hemost 2014;40(03):296-305

18 Johansen ME, Johansson PI, Ostrowski SR, et al. Profound endothelial damage predicts impending organ failure and death in sepsis. Semin Thromb Hemost 2015;41(01):16-25

19 Moore GW. Recent guidelines and recommendations for laboratory detection of lupus anticoagulants. Semin Thromb Hemost 2014;40(02):163-171

20 Yamamoto K, Takeshita K, Saito H. Plasminogen activator inhibitor-1 in aging. Semin Thromb Hemost 2014;40(06):652-659

21 Franchini M, Favaloro EJ, Lippi G. Newer hemostatic agents. Semin Thromb Hemost 2015;41(07):802-808

22 Levi M, van der Poll T. A short contemporary history of disseminated intravascular coagulation. Semin Thromb Hemost 2014;40 (08):874-880

23 Falanga A, Marchetti M. Thrombosis in myeloproliferative neoplasms. Semin Thromb Hemost 2014;40(03):348-358

24 De Stefano V, Za T, Rossi E. Venous thromboembolism in multiple myeloma. Semin Thromb Hemost 2014;40(03):338-347

25 Mallett SV. Clinical utility of viscoelastic tests of coagulation (TEG/ ROTEM) in patients with liver disease and during liver transplantation. Semin Thromb Hemost 2015;41(05):527-537

26 Semeraro N, Ammollo CT, Semeraro F, Colucci M. Coagulopathy of acute sepsis. Semin Thromb Hemost 2015;41(06):650-658

27 Suades R, Padró T, Badimon L. The role of blood-borne microparticles in inflammation and hemostasis. Semin Thromb Hemost 2015;41(06):590-606

28 Turner N, Nolasco L, Nolasco J, Sartain S, Moake J. Thrombotic microangiopathies and the linkage between von Willebrand factor and the alternative complement pathway. Semin Thromb Hemost 2014;40(05):544-550

29 Xiao X, Pickering MC, Smith RJ. C3 glomerulopathy: the genetic and clinical findings in dense deposit disease and C3 glomerulonephritis. Semin Thromb Hemost 2014;40(04):465-471

30 Favaloro EJ. 2016 Eberhard F. Mammen Award announcements: Part I - Most Popular Articles. Semin Thromb Hemost 2016;42 (04):325-330

31 Favaloro EJ. 2016 Eberhard F. Mammen Award Announcements: Part II - Young Investigator Awards. Semin Thromb Hemost 2017; 43(03):235-241 